\title{
Editorial: Hope in the Midst of Ruins
}

Elaine Graham

This issue of Modern Believing is the first of two special editions featuring papers from the Modern Church conference on 'Theology in the Public Square' held in July 2019. While uncertainty over the outcome of the 2016 Referendum on Britain's membership of the European Union (popularly known as Brexit) cast a long shadow over our discussions, other questions also entered the debate. At a time of dwindling organisational strength on the part of traditional mainstream denominations, what role could, or should, the Christian churches play in relation to politics and public policy? How are the voices and interventions of religious faith to be mediated into a public square that is increasingly disinterested, if not hostile, to religion? How can the churches draw on the traditional wisdom of Christian teaching in ways that can contribute critically and constructively to the common good?

I have recently returned from a meeting of the Global Network for Public Theology, a consortium of nearly fifty academic centres specialising in questions of religion and public life. Topics ranged from the significance of public sacred space for national identity with special reference to the rebuilding of Notre Dame in Paris, church ministry alongside refugees, faith-based responses to gender-based violence in South Africa and the implications for many Pacific Islands in the face of climate emergency. Such global issues, often concerned with matters of sheer survival, serve to put our domestic troubles into perspective; and yet I was struck by the similarity of underlying questions of how religious voices and actors make sense of complex and changing public issues and find ways of discerning how to speak and act in light of the gospel. 
Three months on from the Modern Church conference, as I write this editorial, the issue of Brexit still remains unresolved. Parliamentary processes have reached an impasse; and if the constitution is not yet in crisis, it is coming under unprecedented stress. Political opinions and emotions - have become polarised and the register of political discourse has become more heated and antagonistic. Times like these only serve to highlight the extent to which a moral vision, as well as legal and constitutional concerns are, ultimately inescapable and lie at the heart of public life. So, for example, at the end of September, the House of Bishops of the Church of England issued a calling for greater respect within and beyond Parliament, and for a political culture that operated with particular attention to the needs of those whose voices are frequently silenced and marginalised. Similarly, speaking on BBC Radio around the same time, Cardinal Vincent Nichols called for a 'new horizon' or renewed political vision grounded in ideals of neighbourliness, reconciliation and the common good. Worthy as such interventions may be, however, they are fruitless if they go unheeded; so we return to wider questions about the overall purchase that voices of faith can bring to bear on the public imagination: a bishop (or archbishop) may speak, but is anyone listening?

It is to these questions that the articles in this first issue turn. In my introductory article, I introduce some of the precepts of the theory and practice of 'Public Theology' and how it might offer us frameworks of understanding and action. In particular - in an echo of Cardinal Nichols' comments - I consider how the liturgical motif of 'building up our common life' might be put to work. Malcolm Brown offers insights into the criteria by which the institutional church - in this case, the Bishops of the Church of England - makes interventions into public debate, and to what end. Anna Rowlands reflects on her own 
experience of encountering some of the post-Brexit political division, and how traditions of Roman Catholic Social Thought might inform a response.

As we approach the third decade of this century, any public theology must come to terms with what Anna Rowlands calls the 'fractured' body politic: the deep fault-lines of populism, climate emergency, poverty, racism and gender violence. That may require the Western churches to acknowledge their complicity in structures of privilege and complacency; to acquire the habits of a theology of 'lament' and repentance before we are able to practise what the South African theologian Tinyiko Maluleke has called 'hope in the midst of ruins'.

Elaine Graham 